\title{
Osteoblast Interactions Within a Biomimetic Apatite Microenvironment
}

\author{
Eric J. Tsang, ${ }^{1}$ Christopher K. Arakawa, ${ }^{1}$ Patricia A. Zuk ${ }^{2}$ and Benjamin M. Wu ${ }^{1}$ \\ ${ }^{1}$ Department of Bioengineering, Henry Samueli School of Engineering and Applied Sciences, University of California, 5121 \\ Engineering V, Los Angeles, CA 90095, USA; and ${ }^{2}$ Regenerative Bioengineering and Repair Laboratory, Department of \\ Surgery, David Geffen School of Medicine at UCLA, University of California, Los Angeles, CA 90095, USA
}

(Received 13 October 2010; accepted 29 December 2010; published online 14 January 2011)

Associate Editor Daniel Takashi Kamei oversaw the review of this article.

\begin{abstract}
Numerous reports have shown that accelerated apatites can mediate osteoblastic differentiation in vitro and bone formation in vivo. However, how cells interact within the apatite microenvironment remains largely unclear, despite the vast literature available today. In response, this study evaluates the in vitro interactions of a well-characterized osteoblast cell line (MC3T3-E1) with the apatite microenvironment. Specifically, cell attachment, spreading, and viability were evaluated in the presence and absence of serum proteins. Proteins were found to be critical in the mediation of cell-apatite interactions, as adherence of MC3T3-E1 cells to apatite surfaces without protein coatings resulted in significant levels of cell death within $24 \mathrm{~h}$ in serum-free media. In the absence of protein-apatite interaction, cell viability could be "rescued" upon treatment of MC3T3-E1 cells with inhibitors to phosphate $\left(\mathrm{PO}_{4}{ }^{3-}\right)$ transport, suggesting that $\mathrm{PO}_{4}{ }^{3-}$ uptake may play a role in viability. In contrast, rescue was not observed upon treatment with calcium $\left(\mathrm{Ca}^{2+}\right)$ channel inhibitors. Interestingly, a rapid "pull-down" of extracellular $\mathrm{Ca}^{2+}$ and $\mathrm{PO}_{4}{ }^{3-}$ ions onto the apatite surface could be measured upon the incubation of apatites with $\alpha$-MEM, suggesting that cells may be subject to changing levels of $\mathrm{Ca}^{2+}$ and $\mathrm{PO}_{4}{ }^{3-}$ within their microenvironment. Therefore, the biomimetic apatite surface may significantly alter the microenvironment of adherent osteoblasts and, as such, be capable of affecting both cell survival and differentiation.
\end{abstract}

Keywords-Biomimetic apatite, Osteoblast, Protein adsorption.

\section{INTRODUCTION}

Accelerated biomimetic apatite coatings have a history of success in both in vitro ${ }^{11,12}$ and in vivo ${ }^{13}$

\footnotetext{
Address correspondence to Benjamin $\mathrm{M}$. Wu, Department of Bioengineering, Henry Samueli School of Engineering and Applied Sciences, University of California, 5121 Engineering V, Los Angeles, CA 90095, USA. Electronic mail: benwu@ucla.edu
}

studies for bone tissue engineering. Chou et al. ${ }^{12}$ previously showed that the coating of twodimensional surfaces with accelerated apatite could support cell attachment, spreading, viability, and proliferation in standard in vitro culture conditions. The osteoinductive properties of the apatite coatings were made evident by the upregulation of several bone-specific markers such as osteopontin (OPN), osteocalcin (OCN), and bone sialoprotein (BSP) in MC3T3-E1 cells cultured on apatite compared to cells cultured on standard uncoated tissue culture polystyrene (TCPS). Furthermore, it was observed that the apatite surfaces could induce the MC3T3-E1 cells to express these osteogenic markers in the absence of commonly used osteogenic factors such as ascorbic acid and beta-glycerophosphate. On a threedimensional substrate, MC3T3-E1 cells cultured on apatite-coated PLGA scaffolds in vitro also showed significant upregulation of OPN expression at day 3, while OCN and BSP expression was upregulated at 4 weeks relative to cells on non-coated PLGA scaffold controls. ${ }^{11}$ These apatite-coated PLGA scaffolds have also shown potential in improving bone formation in vivo, demonstrating the ability to regenerate bone in critical-size mouse calvarial defects in conjunction with adipose-derived adult stromal cells. ${ }^{13}$ Despite this success of using apatite coatings for bone tissue regeneration, little is known on the exact mechanism that induces the positive biological response of the apatite microenvironment. As a first step in elucidating the relationship between apatite surfaces and the cellular response, MC3T3-E1 preosteoblast cells were cultured, in this study, on apatite-coated TCPS in the presence and absence of proteins, and the effect on adhesion and viability were assessed. 


\section{MATERIALS AND METHODS}

\section{Preparation of Apatite-Coated Surfaces}

Biomimetic apatite-coated surfaces were prepared using an accelerated approach using simulated body fluid solutions $(5 \times \mathrm{SBF} 1$ and $5 \times \mathrm{SBF} 2)$ as previously published. ${ }^{10}$ TCPS wells were coated through an initial incubation with $5 \times \mathrm{SBF} 1$ for $24 \mathrm{~h}$ at $37^{\circ} \mathrm{C}$, followed by a $48 \mathrm{~h}$ incubation (at $37^{\circ} \mathrm{C}$ ) with $5 \times$ SBF2. Each well was then rinsed gently with sterile distilled deionized water and dried in a laminar flow hood overnight.

\section{Apatite Morphology}

Surface morphology and elemental composition $(\mathrm{Ca}$ and $\mathrm{P})$ of the apatite coatings were analyzed with a FEI Nova SEM 230 scanning electron microscope with attached EDS detector (FEI Co., Hillsboro, OR). Sections of apatite-coated TCPS were analyzed with SEM under low-vacuum mode with an accelerating voltage of $10 \mathrm{kV}$. Energy dispersive X-ray analysis (EDS) was performed on the samples to obtain $\mathrm{Ca}$ and $\mathrm{P}$ content of the apatite coatings. ${ }^{12}$

\section{MC3T3-E1 Cell Culture and Viability on Apatite Surfaces}

MC3T3-E1 cells were purchased from ATCC (CRL-2594). The cells were expanded under standard tissue culture conditions in MC3T3-E1 expansion medium (EM) containing $\alpha$-MEM, $10 \%$ FBS, and $1 \%$ penicillin/streptomycin. For experiments performed on bare apatite surfaces, monolayers of MC3T3-E1 cells were prepared for serum-free conditions by incubating in EM containing 5\% FBS for $6 \mathrm{~h}$, followed by $12 \mathrm{~h}$ in serum-free EM. The cells were then harvested using $0.25 \%$ trypsin $/ 2.21 \mathrm{mM}$ EDTA, and resuspended at a desired density in serum-free EM. The apatite surfaces were seeded by incubating with the cell suspension overnight in a $37{ }^{\circ} \mathrm{C}, 5 \% \mathrm{CO}_{2}$ incubator. All tissue culture reagents were purchased from Mediatech CellGro (Manassas, VA).

To assess the effect of adhesion to the apatite surface on cell viability, MC3T3-E1 cells were seeded onto apatite surfaces at $10,000 \mathrm{cells} / \mathrm{cm}^{2}$, and viability determined at select time points up to $24 \mathrm{~h}$ using either a Live/Dead kit (Invitrogen, Carlsbad, CA) or an Alamar Blue assay (AbD Serotec, Oxford, UK). For the Live/Dead assay, cells were incubated at the desired time points with a solution of calcein AM and ethidium homodimer-1 (EthD-1) as outlined by the manufacturer to determine living (green) and dead (red) cells, respectively. For cell quantitation, Alamar Blue reagent, which is metabolically processed by the cells, was added directly to the MC3T3-E1 EM at select time points and the cells incubated for $1 \mathrm{~h}$ at $37^{\circ} \mathrm{C}$. The EM containing the metabolized Alamar Blue was then removed and measured at 535/590 nm (excitation/ emission). Cell number was determined based on these absorbances according to the manufacturer. Viability assays were repeated three times $(n=3)$ and expressed as the average number of viable cells $\pm \mathrm{SD}$.

\section{Protein Adsorption on Apatite Surfaces}

To assess the effect of adsorbed proteins on viability, either FBS or BSA was absorbed to the apatite-coated surfaces. Since FBS contains a variety of proteins including albumin, BSA was also chosen in this study to eliminate possible confounding effects that multiple protein adsorption from FBS may have on influencing cell behavior or function.

For BSA-coated apatite, a $1 \%(\mathrm{w} / \mathrm{v})$ stock solution was made by dissolving BSA protein (\#A9418, Sigma, St. Louis, MO) in PBS $\left(\mathrm{Ca}^{2+}\right.$ and $\mathrm{Mg}^{2+}$ free, Mediatech CellGro, Manassas, VA). The BSA stock solution was sterile filtered and further diluted with sterile 1 XPBS to make 0.1, 0.01, and $0.001 \%$ BSA solutions. FBS solutions were created by the dilution of FBS (Omega Scientific, Tarzana, CA) in sterile $1 \times$ PBS to make concentrations of $10,1,0.1$, and $0.01 \%$ FBS. Apatite-coated 12 -well TCPS plates were then incubated with the BSA and FBS solutions for $12 \mathrm{~h}$ in a $37^{\circ} \mathrm{C}$ incubator. For all wells, the apatite surface area to protein solution volume ratio was $3.9 \mathrm{~cm}^{2} / \mathrm{mL}$. Each well was then rinsed gently three times with $1 \times$ PBS and the amount of protein adsorbed to the apatite surfaces was quantified using BCA assay (Pierce BCA Protein Assay, Thermo, Waltham, MA).

\section{Determination of Caspase Signaling Activity by Immunofluorescence}

To study apoptosis, caspase-3 activity was assessed in MC3T3-E1 cells cultured on apatite surfaces. Cells were cultured at a cell seeding density of 10,000 cells $/ \mathrm{cm}^{2}$ in serum-free EM for $24 \mathrm{~h}$ on bare apatite, $1 \%$ BSA-coated apatite, or bare apatite surfaces in the presence of $1 \mathrm{mM}$ phosphonoformic acid (PFA). The cells were then fixed and probed with antibodies specific for activated caspase-3, washed three times with $1 \times$ PBS for $5 \mathrm{~min} /$ wash, and then incubated with FITC-conjugated goat anti-rabbit secondary antibodies. Cell nuclei were counterstained with DAPI mount (Southern Biotech, Birmingham, AL). As a positive control, MC3T3-E1 cells were cultured on TCPS in the presence of $1 \mu \mathrm{M}$ doxorubicin (Sigma) a DNA 
intercalator that induces apoptosis through the caspase cascade. Staining for caspase activity was observed under fluorescence microscopy (Leica DM IRB, Wetzlar, Germany).

\section{Effect of Caspase Inhibition on MC3T3-E1 Cell Viability upon Culture on Apatite Surfaces}

To further assess the role of apoptosis in cell death on apatite surfaces, MC3T3-E1 cells were cultured on bare apatite in serum-free EM in the presence of the general caspase inhibitor zVAD-fmk. ${ }^{37}$ MC3T3-E1 cells were prepared for serum-free conditions as described above, and treated with various concentrations of zVAD-fmk $(0,10,50,100 \mu \mathrm{M})$ prior to seeding onto apatite. The cells were then seeded at density of $10,000 \mathrm{cell} / \mathrm{cm}^{2}$ onto apatite-coated TCPS, and again treated following seeding with zVAD-fmk at the concentrations listed above for $24 \mathrm{~h}$. Cells cultured on $1 \%$ BSA-coated apatite were used as a control. After $24 \mathrm{~h}$, cell viability was assessed with Live/Dead staining and Alamar Blue as before.

\section{The Effect of Extracellular Calcium $\left(\mathrm{Ca}^{2+}\right)$} and Phosphate $\left(\mathrm{PO}_{4}{ }^{3-}\right)$ on MC3T3-E1 Viability

The effect of $\mathrm{Ca}^{2+}$ and $\mathrm{PO}_{4}{ }^{3-}$ uptake on cell viability was performed by supplementing EM with known amounts of $\mathrm{Ca}^{2+}$ and $\mathrm{PO}_{4}{ }^{3-}$. For this, $10 \mathrm{mM}$ stock solutions of $\mathrm{CaCl}_{2}$ (EMD) and $\mathrm{NaH}_{2} \mathrm{PO}_{4}$ (Sigma) were prepared separately in EM. MC3T3-E1 cells were cultured on TCPS at 10,000 cells $/ \mathrm{cm}^{2}$ for $4 \mathrm{~h}$ in unsupplemented EM to allow cell attachment. After $4 \mathrm{~h}$, the media from each well was replaced with EM supplemented with various concentrations of $\mathrm{Ca}^{2+}$ and $\mathrm{PO}_{4}^{3}$, prepared from the $10 \mathrm{mM}$ stock solutions of $\mathrm{CaCl}_{2}$ and $\mathrm{NaH}_{2} \mathrm{PO}_{4}$. The cells were cultured in the $\mathrm{Ca}^{2+} / \mathrm{PO}_{4}^{3}$-supplemented media for $24 \mathrm{~h}$ and cell viability was assessed using Live/Dead staining or Alamar Blue assay. The $\mathrm{pH}$ of the $\mathrm{Ca}^{2+}$ and $\mathrm{PO}_{4}^{3}$-supplemented EM at each of the different concentrations was measured to verify that the $\mathrm{pH}$ had not altered significantly from physiological $\mathrm{pH}$ (data not shown).

To confirm the effect of $\mathrm{Ca}^{2+}$ and $\mathrm{PO}_{4}{ }^{3-}$ uptake on cell death, MC3T3-E1 cells were incubated in EM containing cytotoxic levels of $\mathrm{Ca}^{2+}$ and $\mathrm{PO}_{4}{ }^{3-}$ in the presence of $\mathrm{Ca}^{2+}$ blockers or $\mathrm{PO}_{4}{ }^{3-}$ transporter inhibitor. Cells were seeded at 10,000 cells $/ \mathrm{cm}^{2}$ on either uncoated or apatite-coated 12-well TCPS plates and immediately treated with EM for $24 \mathrm{~h}$ supplemented with ion transport inhibitor. To block $\mathrm{Ca}^{2+}$ uptake, the L-type $\mathrm{Ca}^{2+}$-channel inhibitors, nifedipine (Sigma) or verapamil (Sigma), or the generalized $\mathrm{Ca}^{2+}$-channel inhibitor lanthanum chloride (Sigma) were added to EM at a concentration ranging from 25 to $100 \mu \mathrm{M}$. To block uptake of $\mathrm{PO}_{4}{ }^{3-}$, the $\mathrm{PO}_{4}{ }^{3-}$ transport inhibitor phosphonoformate (PFA, Sigma) ${ }^{2}$ was added to the culture medium at concentrations ranging from $25 \mu \mathrm{M}$ to $1 \mathrm{mM}$. The effect of these inhibitors on MC3T3-E1 viability was assessed by Live/Dead staining and Alamar Blue assay.

\section{Inductively Coupled Plasma-Optical Emission Spectroscopy and Radio-Labeled Calcium Phosphate Tracking}

Analysis of extracellular $\mathrm{Ca}$ and $\mathrm{P}$ concentration in culture media was performed using inductively coupled plasma-optical emission spectroscopy (ICP-OES). For this, apatite-coated surfaces were incubated in the presence of serum-free $\alpha$-MEM from 15 min to $24 \mathrm{~h}$. Basal levels of $\mathrm{Ca}$ and $\mathrm{P}$ are reported by the manufacturer to be 1.8 and $1.0 \mathrm{mM}$, respectively. The medium from each apatite-coated well was then collected and digested with nitric acid for $2 \mathrm{~h}$ on a $90{ }^{\circ} \mathrm{C}$ heating block. Each digested sample was diluted with glass distilled water until the final concentration of nitric acid reached $5 \%$ to match that of the calibration standards, which contained a known amount of $\mathrm{Ca}$ and $\mathrm{P}$. The samples were then analyzed for elemental $\mathrm{Ca}$ and $\mathrm{P}$ with a TJA Radial Iris 1000 ICP-OES machine (Thermo, Waltham, MA).

To confirm that $\mathrm{Ca}^{2+}$ and $\mathrm{PO}_{4}{ }^{3-}$ ions from culture medium were adsorbing to the apatite surface, $\alpha$-MEM was supplemented with radioactive $\mathrm{Ca}-45$ or $\mathrm{P}-32$ isotopes (MP Biomedicals, Santa Ana, CA) at a concentration of $1 \mu \mathrm{Ci} / \mathrm{mL}$, and incubated over apatitecoated surfaces up to $24 \mathrm{~h}$. The media was collected and radioactivity measured with a Beckman Coulter LS6500 multi-purpose scintillation counter (Beckman Coulter, Brea, CA). In addition, the apatite coatings were digested with $1 \mathrm{mM} \mathrm{HCl}$ from the bottom of each well and their radioactivity also measured to determine the amount of radioactive $\mathrm{Ca}^{2+}$ and $\mathrm{PO}_{4}{ }^{3-}$ adsorbed to the apatite.

\section{RESULTS}

\section{Apatite Morphology}

Apatite surfaces prepared through an accelerated approach ${ }^{10,12}$ showed a plate-like structure, with plate length ranging from approximately $1-5 \mu \mathrm{m}$ (Fig. 1). EDS analysis confirmed that the apatite consisted primarily of $\mathrm{Ca}$ and $\mathrm{P}$, in a $\mathrm{Ca} / \mathrm{P}$ atomic ratio of 1.48 , which is slightly below the reported 1.67 stoichiometric ratio of pure hydroxyapatite, ${ }^{24}$ but is consistent with other apatite coatings prepared from this biomimetic approach. ${ }^{10}$ 


\section{Protein Adsorption on Apatite Surfaces is Required for Cell Viability}

Previous studies have shown that adsorption of serum proteins onto biomaterial surfaces can mitigate cell death. ${ }^{39}$ Consistent with this data, the bare apatite surfaces created in this study rapidly induced the death of MC3T3-E1 cells. Using a Live/Dead immunofluorescent (IF) assay, short-term adhesion to bare apatite (i.e., $1 \mathrm{~h}$ ) did not appear to affect MC3T3-E1 viability, with the majority of the adherent cells capable of metabolically cleaving the calcein AM viability marker.
However, adhesion of cells to bare apatite for only $3 \mathrm{~h}$ began to produce significant levels of cell death (Fig. 2a). Increasing adhesion time to $24 \mathrm{~h}$ resulted in a dramatic increase in cell death with the majority of cells incorporating EthD-1 as a fluorescent marker of dead cells. Quantitatively, a similar time course of increasing cell death was observed using an Alamar Blue assay-an assay that quantifies viable cells through metabolic processing of the Alamar Blue reagent. ${ }^{28}$ As with the Live/Dead assay, the Alamar Blue assay confirmed that the majority of MC3T3-E1
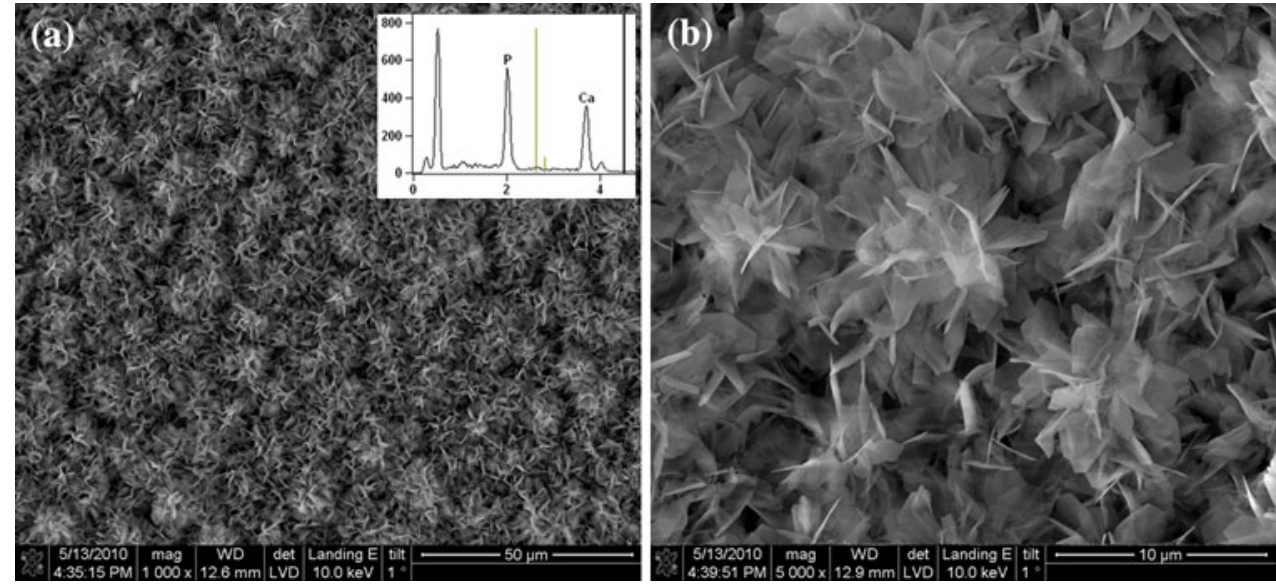

FIGURE 1. Plate-like morphology of biomimetically prepared apatite surfaces. Apatite surfaces were created in tissue culture polystyrene (TCPS) wells using an accelerated biomimetic approach. $\times 1000$ (a) and $\times 5000$ (b) scanning electron micrographs confirm the plate-like morphology of the resulting apatite surface. EDS analysis (a, inset) confirmed the content of calcium and phosphorus with a stoichiometric $\mathrm{Ca} / \mathrm{P}$ ratio of 1.48 .
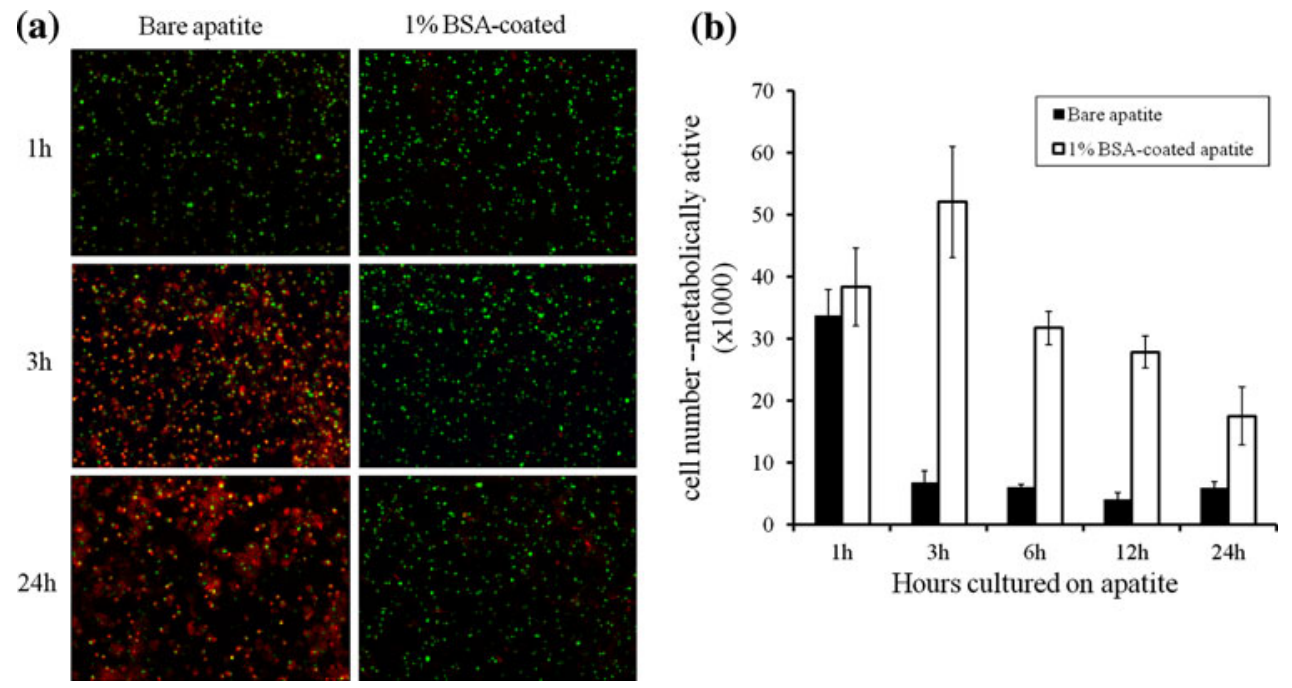

FIGURE 2. Bare apatite surfaces do not support cell viability. (a) MC3T3-E1 cells were seeded on uncoated apatite surfaces (i.e., bare apatite) and viability assessed after 1,3 , and $24 \mathrm{~h}$ using a Live/Dead stain. The majority of cells remain viable (green fluorescence) after $1 \mathrm{~h}$. However, increased cell death (red fluorescence) is observed between 3 and 24 h. MC3T3-E1 cells cultured on $1 \%$ BSA-coated apatite surfaces retained viability at all time points assessed. (b) MC3T3-E1 viability was quantified over $24 \mathrm{~h}$ culture on bare apatite at the indicated times using an Alamar Blue fluorometric assay. The total number of metabolically active (i.e., viable) cells on the apatite surface was determined (cell number - metabolically active $(\times 1000)$ ) and expressed with respect to time (hours cultured on apatite). 
cells, after $1 \mathrm{~h}$ adherence to bare apatite, were still metabolically active (i.e., viable). However, a significant drop in the number of viable cells (i.e., a $79.6 \%$ decrease in viability) was observed after $3 \mathrm{~h}$ (Fig. 2b). Unlike the Live/Dead IF assay, Alamar Blue failed to measure any further decrease in cell viability between 3 and $24 \mathrm{~h}$, whereas there was an obvious drop in viability using the Live/Dead assay. This discrepancy may be due to inherent differences in the sensitivity of these two assays. However, both assays confirm that cellular adhesion to bare apatite layers induces their death.

To mitigate cell death, apatite surfaces, prior to cell seeding, were pre-absorbed with increasing concentrations of BSA or FBS as a source of protein. A simple BCA protein assay confirmed the adsorption of these proteins to the apatite surface (Fig. 3a). For FBS a linear relationship between adsorbed protein and
FBS concentration was observed between the ranges of $0.1-10 \%$. After $12 \mathrm{~h}$ incubation with a $0.01 \%$ FBS solution, the surface coverage of FBS protein on apatite was measured to be approximately $1.1 \mu \mathrm{g} / \mathrm{cm}^{2}$. Increasing the FBS concentration 100-fold to $1.0 \%$ FBS resulted in almost a 1.5-fold increase in adsorbed FBS protein $\left(1.54 \mu \mathrm{g} / \mathrm{cm}^{2}\right)$, while a 1000 -fold increase to $10 \%$ FBS resulted in almost a 1.75 -fold increase $\left(1.84 \mu \mathrm{g} / \mathrm{cm}^{2}\right)$. While not shown, there was no appreciable increase in protein absorption if the FBS concentration was increased beyond $10 \%$ (data not shown). Linearity in the adsorption of BSA to apatite surfaces was not as apparent. However, a moderate linear relationship was observed between the ranges of 0.1 and $0.001 \%$ BSA. For adsorbed BSA on apatite, incubation for $12 \mathrm{~h}$ with a $0.001 \%$ BSA solution resulted in approximately $0.5 \mu \mathrm{g} / \mathrm{cm}^{2}$ surface coverage. (a)
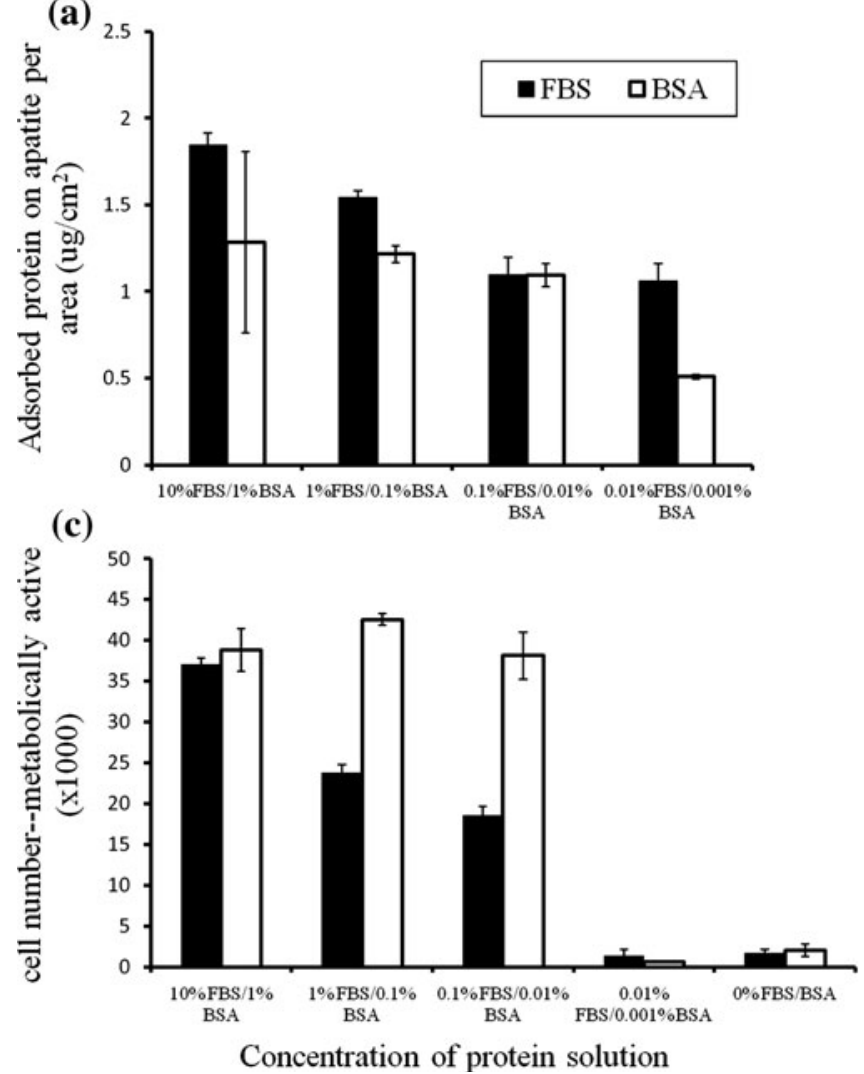

(b)
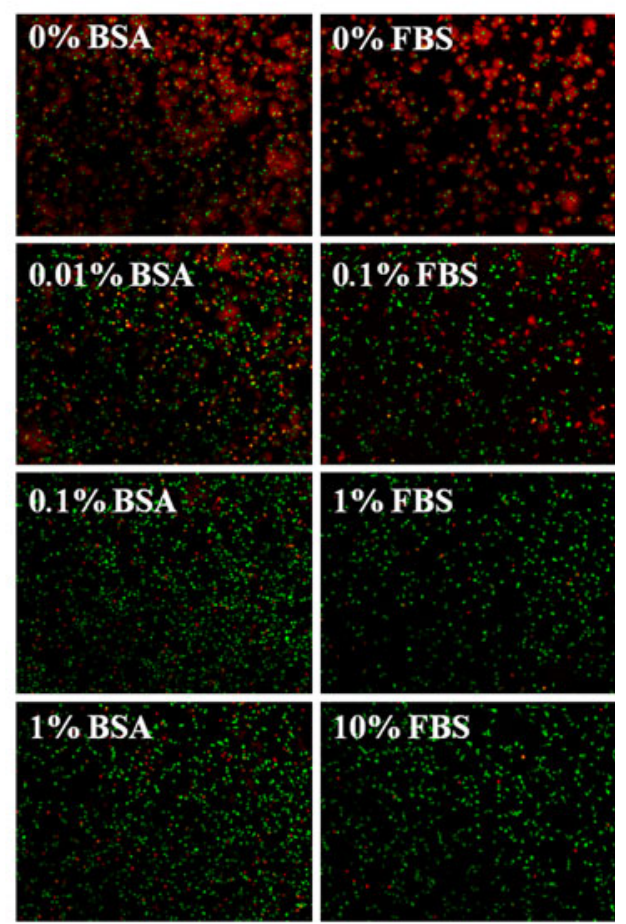

FIGURE 3. Protein adsorption to apatite surfaces can "rescue" MC3T3-E1 viability. (a) Increasing concentrations of either FBS (black bars) or BSA (white bars) were incubated with apatite surfaces for $12 \mathrm{~h}$ to adsorb proteins onto their surface. Protein adsorption was confirmed using a conventional BCA protein assay. Protein adsorption (adsorbed protein on apatite per area) was expressed as $\mu \mathrm{g}$ protein per $\mathrm{cm}^{2}$ apatite surface. (b) MC3T3-E1 viability on bare apatite surfaces (0\% BSA, $0 \%$ FBS) and on surfaces adsorbed to increasing concentration of FBS (right panel $0.1-10 \%$ ) or BSA (left panel $0.01-1.0 \%$ ) was assessed using Live/Dead fluorescent staining. Cell viability shows a dose-dependent response with respect to the amount of protein pre-adsorbed onto the apatite coating prior to cell seeding, with an increasing number of live cells (green fluorescence) and a fewer number of dead cells (red fluorescence) being observed as protein concentration increases. (c) MC3T3-E1 viability on bare and protein-coated apatite surfaces was also quantified using a fluorescent Alamar Blue assay. Viable cells, measured through metabolic Alamar Blue reduction (cell number - metabolically active $(\times 1000)$ ), were expressed with respect to \% protein adsorbed to the apatite surface (Concentration of protein solution). Increasing cell viability on apatite surfaces was dose-dependent, with a minimum protein concentration of $0.1 \%$ FBS or $0.001 \%$ BSA needed to "rescue" cell viability. 
A tenfold increase in the BSA concentration to $0.01 \%$ led to a twofold increase in adsorbed BSA at $1.1 \mu \mathrm{g} / \mathrm{cm}^{2}$. Only a slight increase in BSA adsorption was observed after increasing the BSA solution 100- and 1000-fold, with protein surface coverage of 1.22 and $1.28 \mu \mathrm{g} / \mathrm{cm}^{2}$, being measured, respectively.

Live/Dead staining of MC3T3-E1 cells cultured in serum-free EM on protein-coated apatite surfaces showed that "rescuing" cell viability was related to the amount of pre-adsorbed protein on the apatite surface prior to cell seeding (Fig. 3b). As shown in Fig. 3b, the viability of cells maintained in serum-free media for $24 \mathrm{~h}$ on apatite surfaces with increasing amounts of adsorbed BSA or FBS, increased in a qualitative manner. For example, approximately $50 \%$ of the seeded cells maintained on apatite surfaces pre-treated with a $0.1 \%$ FBS solution remained viable, while nearly all cells remained viable on apatite surfaces pretreated with $10 \%$ FBS. Similarly, MC3T3-E1 cells cultured for $24 \mathrm{~h}$ on apatite surfaces pre-exposed to $0.01 \%$ BSA (i.e., the approximate concentration of albumin found in $0.1 \%$ FBS) showed close to $50 \%$ viability, while protein pre-adsorption with a $1 \%$ BSA solution (i.e., the approximate content of albumin found in $10 \%$ FBS) rescued viability in nearly $100 \%$ of the adherent cells. Quantifying cell metabolic activity as a means of measuring viability confirmed the Live/ Dead studies (Fig. 3c). As with the protein adsorption studies of Fig. 3a, a definitive dose-dependent relationship appeared to exist between FBS concentration and cell viability. In contrast, the effect of BSA on MC3T3-E1 viability was not as linear, but appeared to plateau out at $0.01 \% \mathrm{BSA}$. Increasing the concentration of BSA beyond $0.01 \%$ did not enhance viability in a statistically significant manner.

\section{Apatite-Induced Cell Death is Not Through Caspase-Mediated Apoptosis}

To determine whether apatite-induced cell death was mediated by an apoptotic mechanism, MC3T3-E1 cells were cultured on bare apatite surfaces at various time points and probed for caspase-mediated activation of apoptosis using an antibody specific to cleaved caspase3. As shown in the Live/Dead and Alamar Blue assays, MC3T3-E1 cells cultured on bare apatite for only $1 \mathrm{~h}$ did not show any evidence of caspase- 3 cleavage, consistent with the viable state of these cells at this juncture (Fig. 4a). However, cleaved caspase-3 was still not observed when the culture time was increased to 3 or $24 \mathrm{~h}$ - times in which MC3T3-E1 cell death has been detected (data not shown). In contrast to these results, strong immunofluorescence for cleaved caspase- 3 was observed in positive controls in which cells were treated with $1 \mu \mathrm{M}$ doxorubicin to induce apoptosis.
To determine if other effector caspases known to induce apoptosis (i.e., caspase-6, caspase-7) were mediating MC3T3-E1 cell death, cells were cultured on bare apatite surfaces in the presence of the general caspase inhibitor zVAD-fmk. Over the range of zVAD-fmk concentrations tested $(0,10,50,100 \mu \mathrm{M})$, Live/Dead staining (Fig. 4b) and Alamar Blue viability quantification (Fig. 4c) showed that general inhibition of caspase activity was not sufficient for preventing MC3T3-E1 cell death when cultured on bare apatite. Adsorbed BSA on apatite, however, still demonstrated the ability to mitigate the cytotoxic effects of the apatite surface, with or without the presence of zVADfmk in the medium. Taken together, the lack of caspase- 3 activation and the inability to rescue cell viability through the inhibition of caspase activity, suggest that the mechanism of apatite-induced cell death over $24 \mathrm{~h}$ of culture is not due to caspasemediated apoptosis.

\section{Elevated Levels of $\mathrm{Ca}^{2+}$ in Combination with $\mathrm{PO}_{4}{ }^{3-}$ Can Decrease MC3T3-E1 Cell Viability}

Previous work by Adams et al. ${ }^{2}$ has shown that extracellular $\mathrm{Ca}^{2+}$ and $\mathrm{PO}_{4}{ }^{3-}$ can decrease the viability of human osteoblast-like cells and MC3T3-E1 murine pre-osteoblast cells in a dose-dependent manner. Since biomimetic apatite surfaces are composed primarily of $\mathrm{Ca}^{2+}$ and $\mathrm{PO}_{4}{ }^{3-}$, it is possible that the release of these ions into the medium upon culture onto apatites could expose MC3T3-E1 cells to elevated levels of these ions. To confirm the effects of elevated extracellular $\mathrm{Ca}^{2+}$ and $\mathrm{PO}_{4}{ }^{3-}$ on MC3T3-E1 viability, MC3T3-E1 cells were cultured on TCPS in basal EM, containing $1.8 \mathrm{mM}$ total $\mathrm{Ca}^{2+}$ and $1.0 \mathrm{mM}$ total $\mathrm{PO}_{4}{ }^{3-}$ and in EM supplemented with increasing concentrations of these two ions. Using Alamar Blue to quantify cell viability (Fig. 5a), it was confirmed that exposure of cells to elevated extracellular $\mathrm{Ca}^{2+}$ and $\mathrm{PO}_{4}{ }^{3-}$ resulted in a decrease in MC3T3-E1 viability. Cell death by $\mathrm{Ca}^{2+}$ and $\mathrm{PO}_{4}{ }^{3-}$ ions was concentrationdependent and required the presence of both ions for maximal effect. For example, when the concentration of extracellular $\mathrm{Ca}^{2+}$ was held constant at its basal level of $1.8 \mathrm{mM}$, increasing extracellular $\mathrm{PO}_{4}{ }^{3-}$ levels (e.g., $2.5-10 \mathrm{mM}$ ) did not significantly alter cell viability. Likewise, when cells were cultured at basal $\mathrm{PO}_{4}{ }^{3-}$ levels (i.e., $1.0 \mathrm{mM}$ ), increasing extracellular $\mathrm{Ca}^{2+}$ concentrations (i.e., $2.5-10 \mathrm{mM}$ ) had no significant effect on cell death. However, when both the concentrations of $\mathrm{Ca}^{2+}$ and $\mathrm{PO}_{4}{ }^{3-}$ were increased, MC3T3-E1 cell death levels also increased. Increasing extracellular $\mathrm{PO}_{4}{ }^{3-}$ to $5.0 \mathrm{mM}$, combined with increasing $\mathrm{Ca}^{2+}$ levels to $5.0 \mathrm{mM}$ led to nearly a $33 \%$ decrease in the number of viable cells, while increasing 
(a)
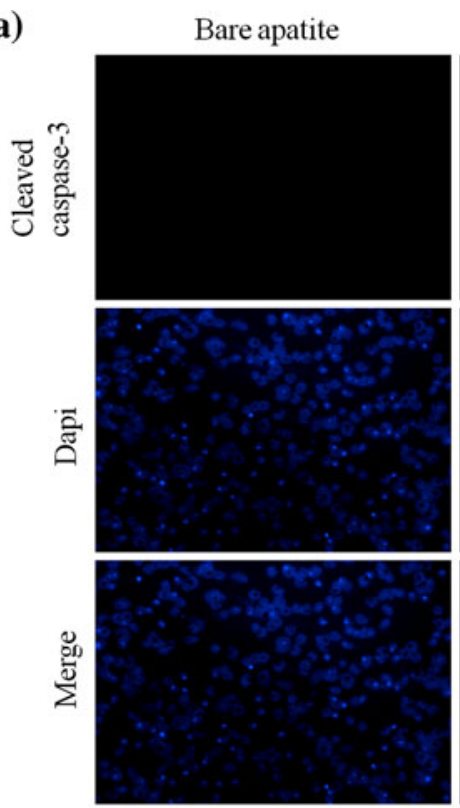
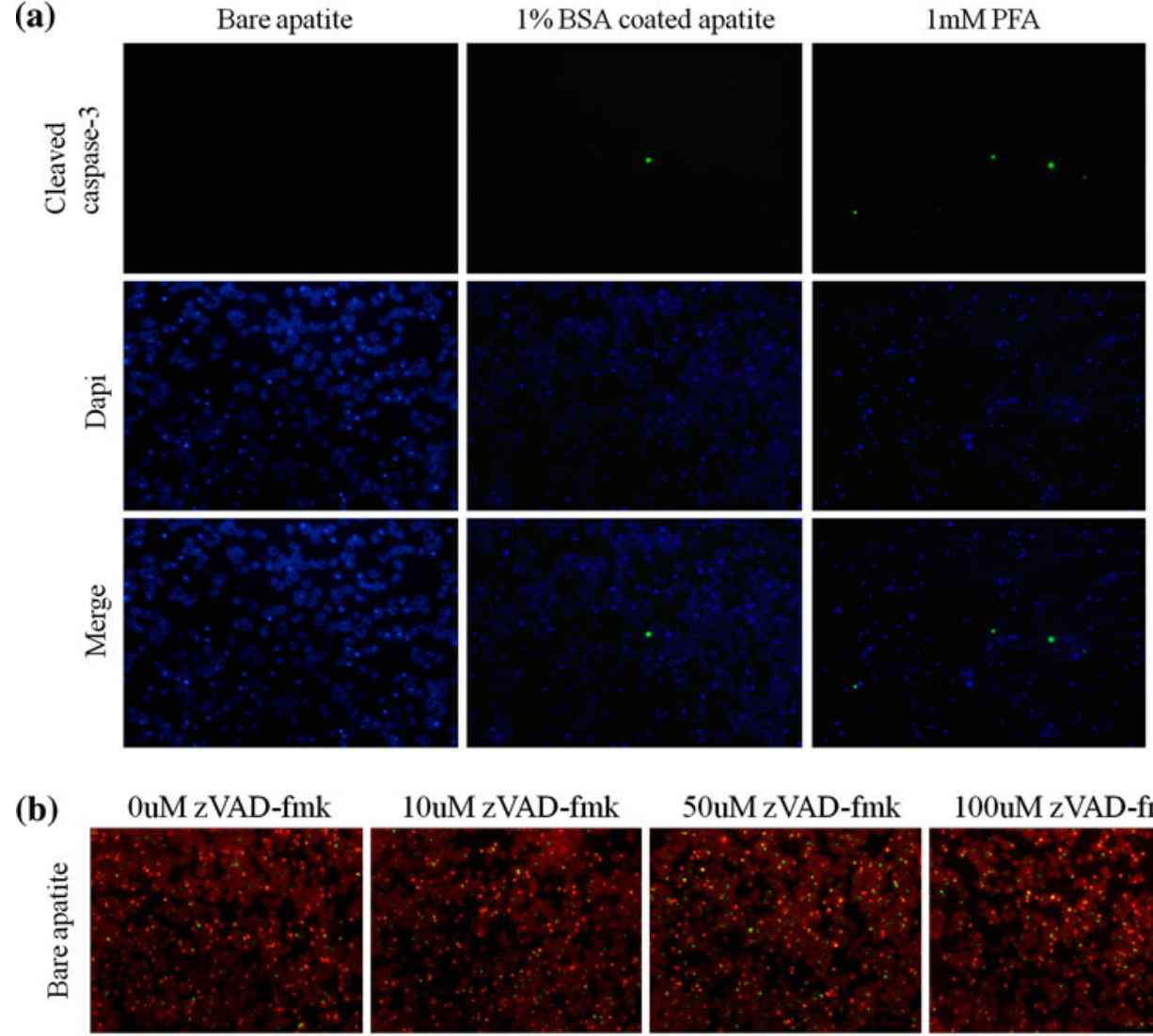

10uM zVAD-fmk

$50 \mathrm{uMzVAD}-\mathrm{fmk}$

100uM zVAD-fmk
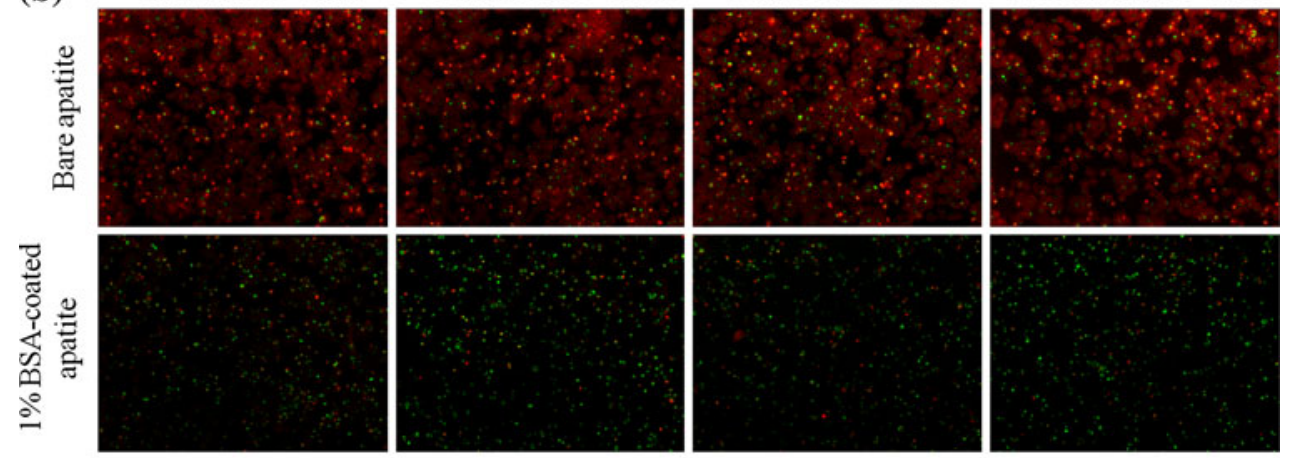

(c)

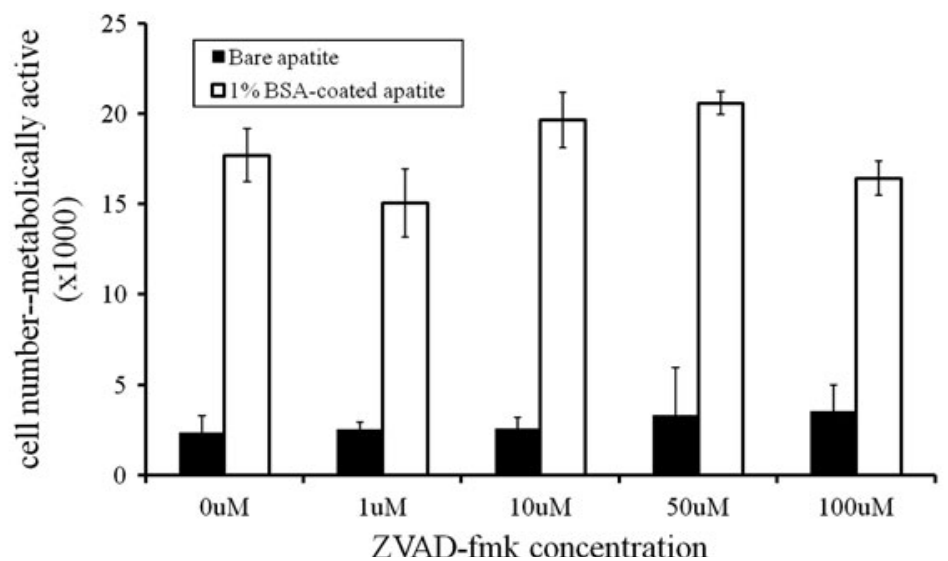

FIGURE 4. MСЗT3-E1 cell death on bare apatite surfaces is not mediated through a caspase-dependent apoptotic pathway. (a) MC3T3-E1 cells were cultured on bare apatite (left pane/), 1\% BSA-coated apatite (center panel), or bare apatite with 1 mM PFA (right panel) for $1 \mathrm{~h}$ and then analyzed for immunofluorescent staining of activated caspase-3 (cleaved caspase 3-green fluorescence). Cell nuclei were counterstained with DAPI (blue) and the images merged. (b) MC3T3-E1 cells cultured on bare apatite (black bars) or 1\% BSA-coated apatite surfaces (white bars) for $24 \mathrm{~h}$ in the presence of the general caspase inhibitor zVAD-fmk. Cell viability was assessed with Live (green)/Dead (red) staining. (c) Quantification of cell viability on bare apatite vs. $1 \%$ BSA-coated apatite in the presence of zVAD-fmk was assessed using fluorescent Alamar Blue assay. The number of viable cells (cell number - metabolically active $(\times 1000)$ ) was expressed with respect to the $\mu \mathrm{M}$ concentration of zVAD-fmk. 
(a)

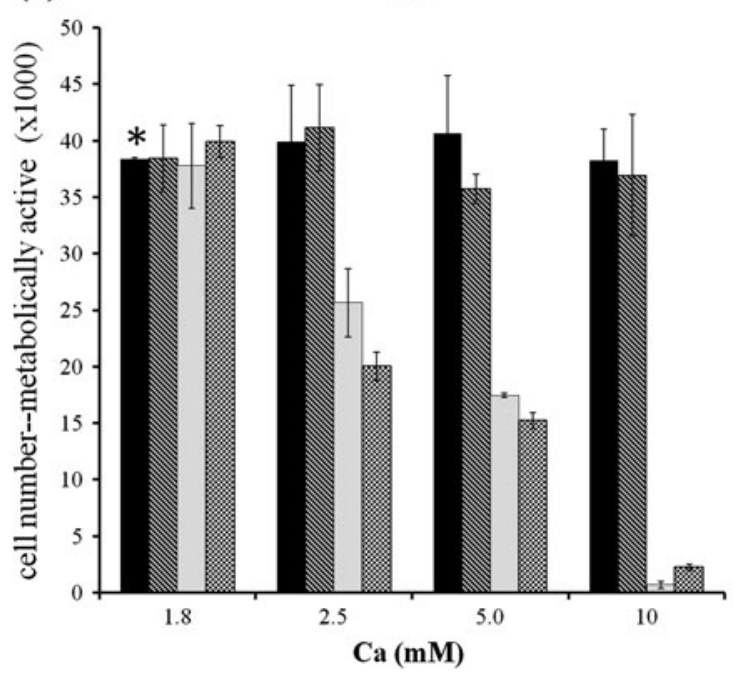

(b)

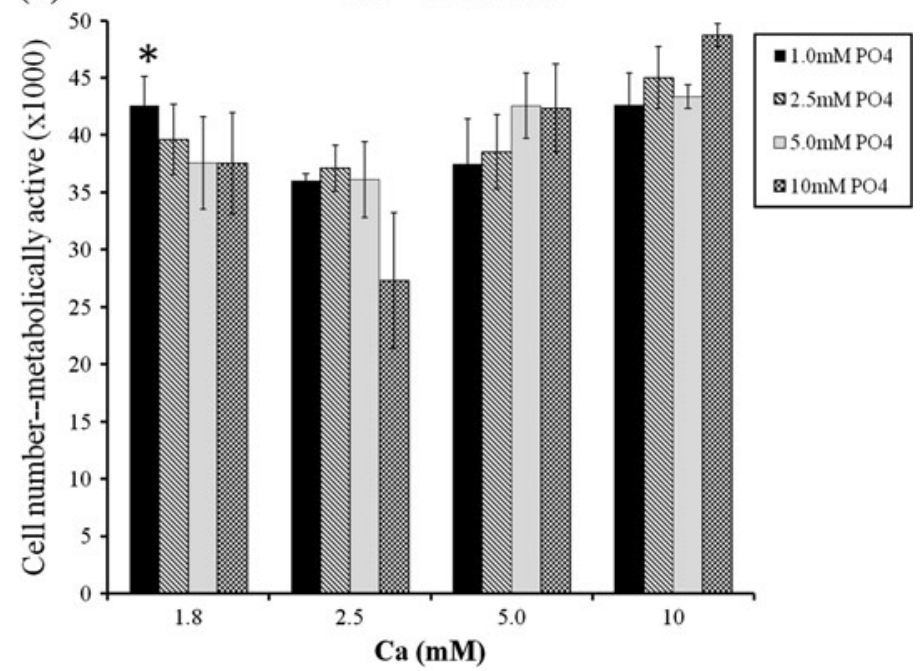

FIGURE 5. Extracellular $\mathrm{Ca}^{2+}$ and phosphate can affect MC3T3-E1 cell viability. (a) MC3T3-E1 cells were cultured on TCPS for $24 \mathrm{~h}$ in EM supplemented with extracellular $\mathrm{Ca}^{2+}$ (total range: 1.8-10 $\mathrm{mM}$ ) and phosphate ions (total range: 1.0-10.0 mM). Unsupplemented EM containing basal $\mathrm{Ca}^{2+}$ and phosphate levels of 1.8 and $1.0 \mathrm{mM}$, respectively, is shown with an asterisk. The number of viable cells (cell number - metabolically active $(\times 1000)$ ) was quantified using an Alamar Blue assay and expressed with respect to calcium and phosphate levels. In the presence of increased phosphate, increasing the amount of supplemented $\mathrm{Ca}^{2+}$ leads to an increase in cell death. (b) MC3T3-E1 cells were prepared as in (a), but in the presence of the Na-Pi co-transport inhibitor PFA. Alamar Blue viability assay demonstrated that extracellular calcium and phosphate ion-induced cell death could be inhibited with PFA.

$\mathrm{Ca}^{2+}$ further to $10 \mathrm{mM}$ decreased cell viability $98 \%$. Similarly, when $\mathrm{PO}_{4}{ }^{3-}$ levels were increased to their maximal level of $10 \mathrm{mM}$, a $\mathrm{Ca}^{2+}$ concentration of $5.0 \mathrm{mM}$ resulted in a $50 \%$ drop in viable cells, while a $\mathrm{Ca}^{2+}$ concentration of $10 \mathrm{mM}$ decreased cell viability $95 \%$. Taken together, the results confirmed previous studies showing that the ion-pairing of extracellular $\mathrm{Ca}^{2+}$ and $\mathrm{PO}_{4}{ }^{3-}$ at specific concentrations can be cytotoxic to MC3T3-E1 cells. Moreover, the data indicates that at higher levels of $\mathrm{PO}_{4}{ }^{3-}$ (i.e., 5, $10 \mathrm{mM}$ ), elevating extracellular $\mathrm{Ca}^{2+}$ levels can dramatically decrease cell viability.

To further confirm the cytotoxic effects of $\mathrm{Ca}^{2+}$ and $\mathrm{PO}_{4}{ }^{3-}$ on MC3T3-E1 viability, cells, incubated on TCPS in the presence of cytotoxic levels of extracellular $\mathrm{Ca}^{2+}$ and $\mathrm{PO}_{4}{ }^{3-}$, were treated with the $\mathrm{Na}-\mathrm{Pi}$ co-transporter inhibitor PFA, to block $\mathrm{PO}_{4}{ }^{3-}$ entry into the cell, followed by an assessment of their viability. Results from the Alamar Blue assay confirmed previous studies ${ }^{2}$ showing that administering PFA results in the "rescue" of MC3T3-E1 viability (Fig. 5b). At the higher levels of extracellular $\mathrm{PO}_{4}{ }^{3-}$ (i.e., $5,10 \mathrm{mM}$ ), which were shown to be cytotoxic in this study with a slight increase in extracellular $\mathrm{Ca}^{2+}$, a delivered dose of $1 \mathrm{mM}$ PFA was sufficient to significantly reduce the amount of cell death that was observed above. In contrast, as has been shown previously, ${ }^{2}$ although the blockage of $\mathrm{PO}_{4}{ }^{3-}$ transporters was sufficient to inhibit the $\mathrm{Ca}^{2+} / \mathrm{PO}_{4}{ }^{3-}$-induced cell death, treatment of cells with L-type $\mathrm{Ca}^{2+}$ channel blockers (nifedipine or verapamil) and a general $\mathrm{Ca}^{2+}$ channel blocker (lanthanum chloride) did little to mitigate cell death in the presence of elevated extracellular $\mathrm{Ca}^{2+}$ and $\mathrm{PO}_{4}{ }^{3-}$ (data not shown).

\section{Apatite Surfaces in Culture Medium Induce the "Pull-Down" of Extracellular $\mathrm{Ca}^{2+}$ and $\mathrm{PO}_{4}{ }^{3-}$}

As shown above, increasing levels of extracellular $\mathrm{Ca}^{2+}$ and $\mathrm{PO}_{4}{ }^{3-}$ can be cytotoxic to adherent MC3T3-E1 cells. Since biomimetic apatite surfaces are composed primarily of $\mathrm{Ca}^{2+}$ and $\mathrm{PO}_{4}{ }^{3-}$, the observed cell death upon adherence of MC3T3-E1 cells to bare apatite may be the result of localized degradation of the apatite in culture conditions, thus elevating extracellular levels of these ions. Therefore, the stability of the apatite surface in culture was measured using ICPOES. For this, acellular, bare apatite surfaces were incubated in serum-free $\alpha$-MEM (as a component of EM) for up to $24 \mathrm{~h}$ and extracellular levels of calcium and phosphorus (as a component of phosphate) were measured by ICP-OES (Fig. 6a). Consistent with reported values, basal levels of calcium and phosphorus within serum-free $\alpha$-MEM was measured at 1.8 and $1.0 \mathrm{mM}$, respectively. During the first $3 \mathrm{~h}$ of incubation on apatite surfaces, the concentration of calcium and phosphorus within the $\alpha$-MEM decreased to approximately $53 \pm 0.041 \%$ and $63 \pm 0.032 \%$ of their original concentrations, respectively, suggesting that the apatite layer may "pull-down" these ions from the 
(a)

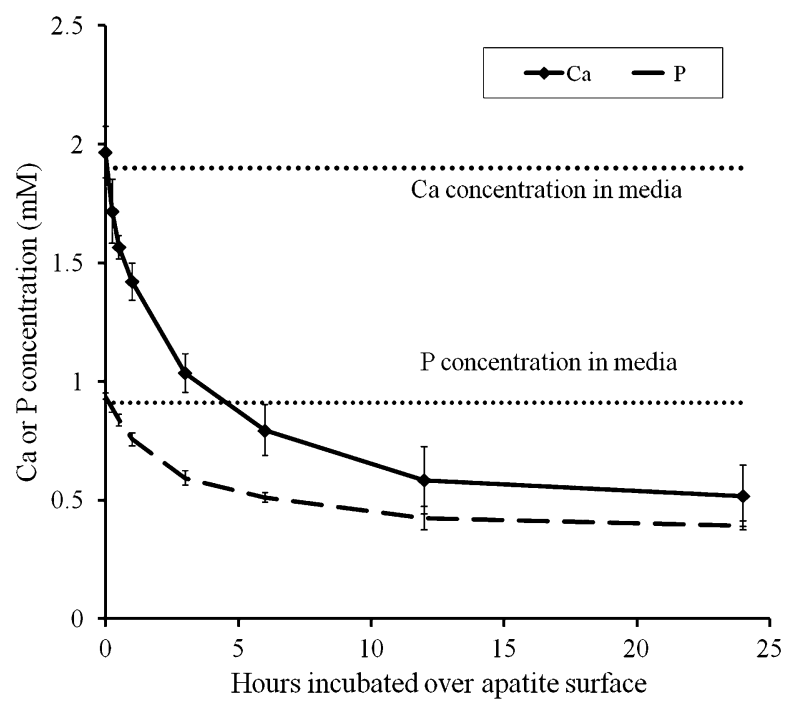

(b)

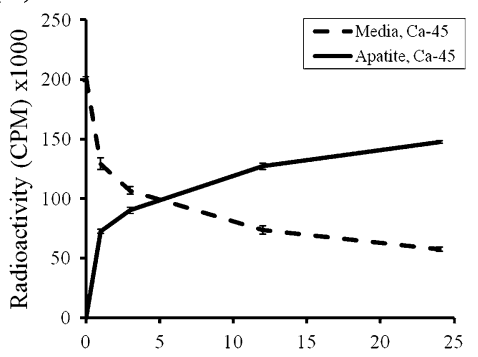

(c)

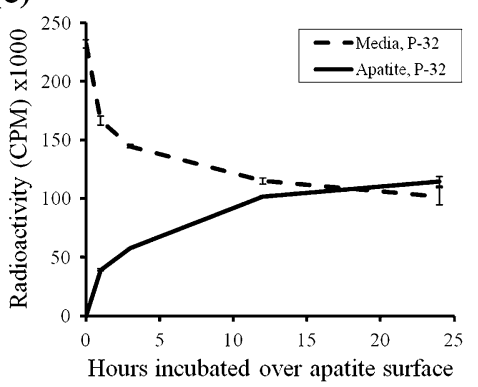

FIGURE 6. Apatite surfaces induce the "pull-down" of calcium and phosphate from the culture media. (a) Acellular apatite surfaces were incubated in serum-free $\alpha$-MEM for up to $24 \mathrm{~h}$. At the indicated times (hours incubated over apatite), the media was removed and subject to ICP-OES analysis to measure the concentrations of $\mathrm{Ca}$ and $\mathbf{P}$ ions within the media (Ca or $\mathbf{P}$ concentration (mM)). ICP-OES shows a progressive removal of $\mathrm{Ca}$ and $\mathrm{P}$ ions from the culture media within the first $6 \mathrm{~h}$, suggesting that these ions are "pulled" out of the media and deposit onto the apatite surface. Levels for Ca and P in alpha-MEM reported by the manufacturer were measured by ICP-OES prior to incubation on apatite surfaces and are shown (dotted lines). (b, c) To confirm the ICP-OES results, serum-free $\alpha$-MEM was supplemented with radioactive Ca-45 (b) or P-32 (c) and incubated on acellular apatite surfaces for various lengths of time up to $24 \mathrm{~h}$ (hours incubated over apatite). The media was then removed, followed by solubilization of the apatite in $\mathrm{HCl}$. Radioactivity, in counts per minute (CPM) was measured in both media and apatite sample (radioactivity $(\mathrm{CPM}) \times 1000)$. A time-dependent decrease in radioactivity within the media was observed (dashed lines), confirming the "pull-down" effect of Ca and P ions from the media onto the apatite surface. Solubilized apatite coatings showed increases in radioactivity (solid lines) that correlated almost exactly to the decrease in radioactivity in the media.

overlying medium. After $12 \mathrm{~h}$, this calcium and phosphorus ion "pull-down" reached equilibrium, stabilizing at a concentration of approximately $0.58 \pm$ $0.14 \mathrm{mM} \mathrm{Ca}$ and $0.42 \pm 0.04 \mathrm{mM} \mathrm{P}$, decreasing to $32 \pm 0.072 \%$ and $44 \pm 0.053 \%$ of the basal levels, respectively. ICP-OES analysis of medium incubated over apatite surfaces for an additional $48 \mathrm{~h}$ (i.e., $72 \mathrm{~h}$ total) did not detect any further change in the levels of extracellular calcium and phosphorus. Taken together, the ICP-OES data suggests that the apatite surface does not significantly release $\mathrm{Ca}^{2+}$ and $\mathrm{PO}_{4}{ }^{3-}$ ions into the extracellular environment but may induce a "pull-down" of these ions from the culture medium.

To confirm this data, apatite surfaces were cultured with serum-free $\alpha$-MEM containing radioactive $\mathrm{Ca}-45$ and P-32. After $3 \mathrm{~h}$ incubation over apatite surfaces, the radioactivity of $\mathrm{Ca}-45$ and $\mathrm{P}-32$ in the serum-free $\alpha$-MEM fell to levels nearly identical to that obtained from ICP-OES. (Figs. 6b, 6c, dashed lines). The amount of radioactive $\mathrm{Ca}-45$ and $\mathrm{P}-32$ in the medium fell to $53 \pm 0.017 \%$ and $62 \pm 0.0067 \%$, respectively. Similar to the results obtained by ICP-OES, the decrease in $\mathrm{Ca}-45$ and $\mathrm{P}-32$ in the medium began to level off after $12 \mathrm{~h}$ incubation over apatite at approximately $36 \pm 0.017 \%$ of the starting $\mathrm{Ca}-45$ levels and $49 \pm 0.011 \%$ of the P-32 initially added to the serum-free medium.

After removal of the $\mathrm{Ca}-45$ and P-32-supplemented $\alpha$-MEM from the apatite-coated wells at each time point, the apatite coatings were dissolved with dilute $\mathrm{HCl}$ and the amount of $\mathrm{Ca}-45$ and $\mathrm{P}-32$ that had deposited on the surfaces were measured. The radioactivity of deposited $\mathrm{Ca}-45$ and P-32 onto the apatite surface correlated almost identically to the amount of radioactive material that had been depleted from the Ca-45 and P-32-supplemented medium collected at each time point (Figs. 6b, 6c, solid lines). Along with the ICP-OES data, these results suggest that the apatite surfaces are capable of altering local extracellular ionic $\mathrm{Ca}^{2+}$ and $\mathrm{PO}_{4}{ }^{3-}$ concentrations that are presented to the cultured MC3T3-E1 cells.

\section{Inhibition of $\mathrm{PO}_{4}{ }^{3-}$ Uptake Can "Rescue"} MC3T3-E1 Viability upon Culture on Apatite Surfaces

The results from this study, as well as those obtained by others, ${ }^{2}$ suggest that the inhibition specifically of $\mathrm{Na}-\mathrm{Pi}$ co-transporters can rescue viability 
of MC3T3-E1 cells cultured on TCPS in the presence of cytotoxic levels of $\mathrm{Ca}^{2+}$ and $\mathrm{PO}_{4}{ }^{3-}$. Therefore, the viability of MC3T3-E1 cells cultured on bare apatite was assessed in the presence of PFA. Consistent with our studies on TCPS, live-dead staining (Fig. 7a) and Alamar Blue quantitation (Fig. 7b) showed a concentration-dependent effect of the ability of PFA to rescue MC3T3-E1 viability, with the minimum concentration required for significant rescue at $500 \mu \mathrm{M}$. As expected, pre-coating apatite surfaces with $1 \%$ BSA negated the cytotoxic effect of the apatite surface. To assess if increasing levels of PFA could compound the toxicity of the apatite surface, cells were cultured on apatite surfaces coated with $1 \%$ BSA as a control and treated with increasing amounts of PFA. Viability levels were unchanged on these BSA-coated surfaces in the presence of increasing PFA, indicating a lack of toxicity by PFA. The observed rescue was specific to $\mathrm{PO}_{4}{ }^{3-}$ uptake as MC3T3-E1 cells cultured on apatite and treated with the $\mathrm{Ca}^{2+}$ channel inhibitors nifedipine, verapamil, or lanthanum chloride, showed similar levels of cell death when compared to samples cultured on apatite in the absence of these inhibitors (Fig. 8). Viability levels were unchanged as concentrations of lanthanum chloride were increased on BSA-coated surfaces, indicating a lack of toxicity attributable to this inhibitor. However, a possible toxic effect was observed for nifedipine, with levels above $5 \mu \mathrm{M}$ decreasing the viability of cells cultured on BSAcoated apatite controls. However, even at subtoxic nifedipine levels (i.e., 1 and $5 \mu \mathrm{M}$ ), this inhibitor was still unable to rescue MC3T3-E1 viability on bare apatite surfaces. Based on these results, it is possible that the observed death of MC3T3-E1 cells cultured

(a)
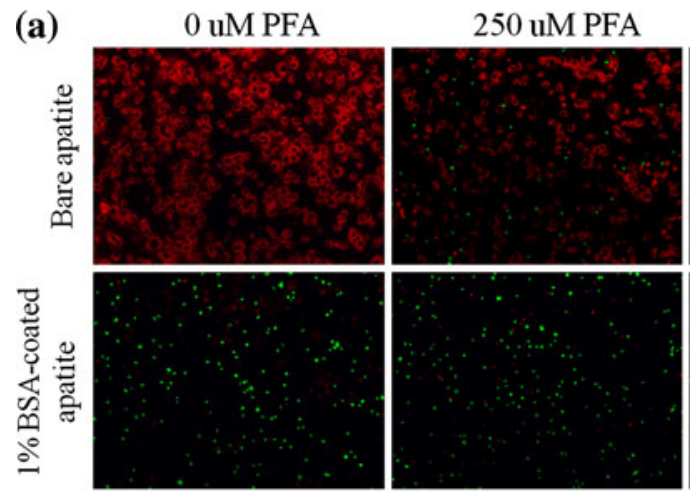

(b)

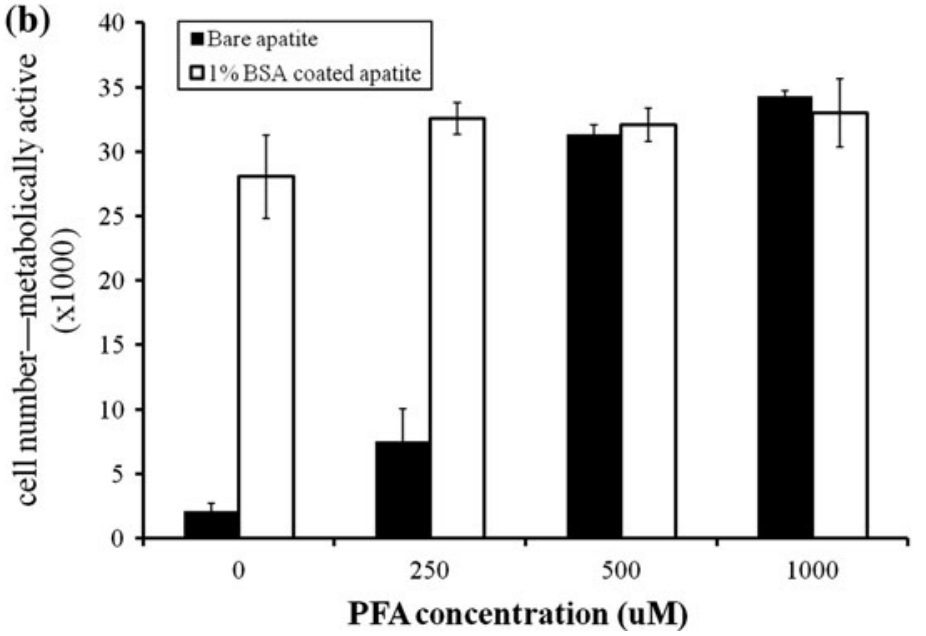

FIGURE 7. Blocking the uptake of phosphate ions can rescue the viability of MC3T3-E1 cells cultured on bare apatite. MC3T3-E1 cells were cultured for $24 \mathrm{~h}$ on bare apatite in EM supplemented with the Na-Pi co-transport inhibitor phosphonoformate (PFA) at the indicated concentrations to block entry of phosphate into the cells. Viable cells (green fluorescence) and dead cells (red fluorescence) were detected using a Live/Dead viability cytotoxicity stain. MC3T3-E1 cells were also cultured with PFA on apatite surfaces coated with $1 \%$ BSA (1\% BSA-coated apatite) as a control for the effects of this inhibitor. Increasing levels of viable cells on bare apatite treated with increasing levels of PFA suggests that blocking phosphate uptake can "rescue" MC3T3-E1 cells from apatite-induced cell death. (b) MC3T3-E1 cells were cultured on either bare apatite (black bars) or $1 \%$ BSA-coated apatite (white bars) as a control, and the number of viable cells was determined via Alamar Blue assay (cell number - metabolically active $(\times 1000)$ ). Increasing amounts of PFA appears to increase MC3T3-E1 viability on bare apatite with a concentration of $500 \mu$ M rescuing the majority of cells. 
(a)

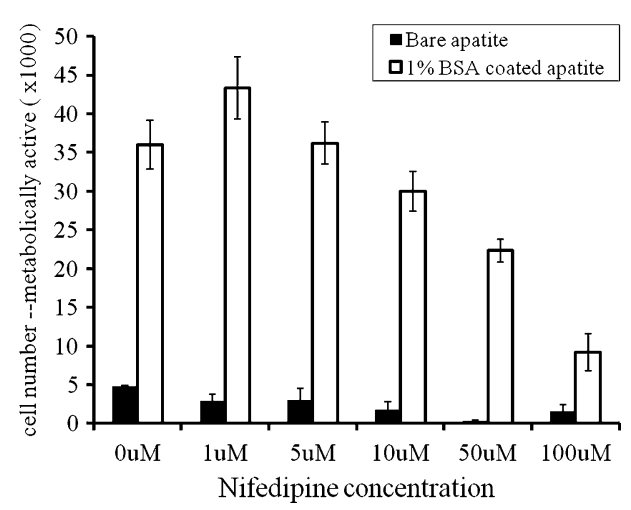

(c)

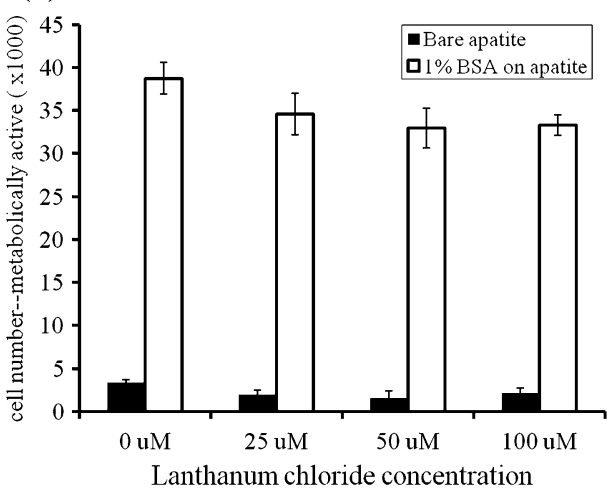

(b)

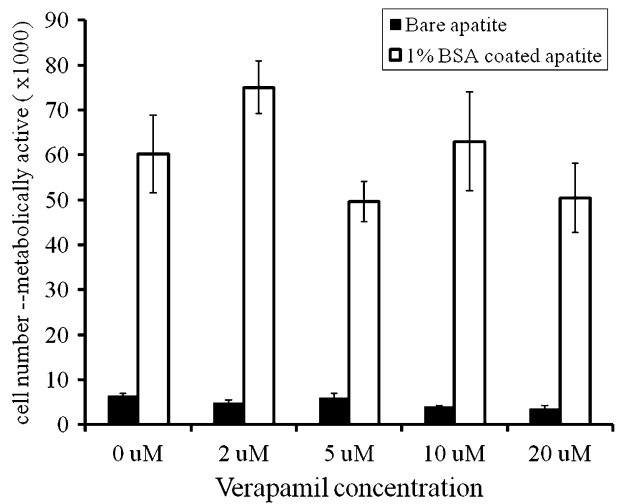

FIGURE 8. Blocking the uptake of calcium ions has no effect on the viability of MC3T3-E1 cells cultured on bare apatite. MC3T3E1 cells were cultured for $24 \mathrm{~h}$ on bare apatite in EM supplemented with the L-type calcium channel inhibitors (a) nifedipine, and (b) verapamil and the general calcium channel blocker (c) lanthanum chloride at the concentrations shown (black bars). MC3T3 cells were also cultured with these inhibitors on apatite surfaces coated with $1 \%$ BSA (1\% BSA on apatite) as a control for the effects of this inhibitor (white bars). The number of viable cells (cell number - metabolically active $(\times 1000)$ ) was measured via Alamar Blue assay. At the given concentrations indicated below, treatment with calcium channel blockers was not able to "rescue" viability of MC3T3-E1 cells cultured on bare apatite surfaces. Treatment with higher concentrations of nifedipine (i.e., 10-100 $\mu \mathrm{M}$ ) indicated a possible toxic effect of this calcium channel blocker to control cells cultured on $1 \%$ BSA-coated apatite, while lack of toxicity was observed for the given concentrations of verapamil and lanthanum chloride.

on bare apatite is due to the specific uptake of $\mathrm{PO}_{4}{ }^{3-}$ ions into the cell.

\section{DISCUSSION}

Despite the evidence suggesting that accelerated biomimetic apatite coatings are capable of mediating osteoblastic differentiation in vitro ${ }^{11,12}$ and new bone formation in vivo, ${ }^{13}$ the exact mechanisms by which cells interact with biomimetic apatite coatings to elicit these osteogenic responses remains largely unknown, and few studies in the literature have studied the direct cell-apatite relationship closely. As such, this study attempts to more closely examine the relationship between the apatite layer and the cellular response. In the in vivo environment, apatite materials are very biocompatible. However, performing the in vitro experiments in this study allows us to dissect the apatite microenvironment and evaluate the relative contribution of each component in this highly complex, dynamic system. To accomplish this, MC3T3-E1 pre-osteoblasts were cultured on apatite surfaces and the effect of this surface on the adhesion and viability of these cells was assessed.

As was previously shown, ${ }^{10}$ apatite coatings prepared from an accelerated biomimetic approach resulted in a uniform coating consisting of $\mathrm{Ca}^{2+}$ and $\mathrm{PO}_{4}{ }^{3-}$ ions in a calcium/phosphorus atomic ratio of 1.48 , which is below the stoichiometric ratio of 1.67 for hydroxyapatite. The coating consists of distinct platelike apatite crystals around amorphous calcium phosphates. Electron diffraction of the calcium-deficient, plate-like apatite crystal revealed diffraction patterns at $d_{1}=2.81 \AA, d_{2}=3.44 \AA$, and $d_{3}=2.72 \AA$ which correspond to $\left(\begin{array}{lll}2 & 1 & 1\end{array}\right),\left(\begin{array}{lll}0 & 0 & 2\end{array}\right)$, and ( $\left(\begin{array}{lll}1 & 1 & 2\end{array}\right)$ planes of hydroxyapatite, respectively. ${ }^{10}$ Although the direct effect of apatite crystal structure on cell viability remains largely undiscovered, it is known, however, that the crystalline phase of the apatite contributes to 
its stability and consequently its dissolution rate. ${ }^{14,29} \mathrm{It}$ is known that both the amorphous and crystalline phases undergo continuous phase transformation, and fluctuations in $\mathrm{Ca}^{2+}$ and $\mathrm{PO}_{3}{ }^{4-}$ levels may contribute significantly to changes in the overall microenvironment and subsequent in vitro cellular response.

Consistent with previous studies, ${ }^{36}$ MC3T3-E1 cells rapidly adhered to uncoated apatite materials (i.e., bare apatite). However, cell death began to appear within the first $3 \mathrm{~h}$ post-seeding with increasing levels of cell death becoming apparent as culture time increased. The reason for this rapid cell death was found not to be due to canonical apoptotic mechanisms. Cells undergoing apoptosis, or "programmed cell death," typically commit to one of two distinct pathways (extrinsic or intrinsic) that converge upon one or more effector caspases (capase-3, -6, -7), whose activation results in cell death. ${ }^{22}$ Our results, however, showed that the bare apatite surface did not induce activation of caspase-3 within adherent MC3T3-E1 cells, nor did inhibition of caspase activation by the general caspase inhibitor zVAD-fmk prevent cell death. Although our experiments preclude activation of the caspase cascade as the mechanism of death in MC3T3-E1 cells cultured on bare apatite, it is still possible that cell death via apoptosis may be occurring through caspase-independent pathways. ${ }^{9}$

Morphologically, apoptosis is generally marked by membrane blebbing, chromatin condensation, and DNA fragmentation. ${ }^{34,38}$ In this study, DAPI staining as well as EthD-1 (dead) staining of cell nuclei clearly show that cells cultured on bare apatite exhibit significant alteration of nuclear morphology. However, instead of DNA condensation both DAPI and EthD-1 show a very diffuse staining pattern, suggesting that DNA dispersion outside the nuclear envelope may be occurring when cells are cultured on bare apatite. This result may further suggest that when cultured on bare apatite surfaces, the mechanism of apatite-induced cell death over $24 \mathrm{~h}$ of culture is not due to caspasemediated apoptosis. A more likely scenario is death caused by necrosis, which is generally highlighted by nuclear swelling, early plasma membrane rupture and release of cellular contents. ${ }^{18}$ Further morphological examination of MC3T3-E1 cells on apatite will be needed to determine whether the mechanism of apatite-induced cell death is through a necrotic process.

While bare apatite surfaces rapidly induced cell death, mitigation of cell death was observed upon precoating the apatite with either BSA or FBS. Previous studies have suggested that adsorbed protein layers mediate the interaction between cells and biomaterials, including biomimetic apatite coatings, promoting cell adhesion and survival. ${ }^{15,21,25,33} \mathrm{~A}$ possible mechanism by which adsorbed proteins decrease cell death on apatite may be the activation of pro-survival intracellular signaling, initiated via membrane-bound integrin receptors and their transduction of the extracellular environment into intracellular signals that govern changes in cell function, including survival. ${ }^{8}$ It has been shown in many cell types, including osteoblasts, that survival signals are mediated through integrinECM interactions. ${ }^{16,17}$ For example, MC3T3-E1 attachment to surfaces, modified with the ECMintegrin motif RGDS, can reduce apoptosis and promote their survival in the presence of various apoptogens. ${ }^{19}$ Moreover, this attachment activates several signaling pathways thought to mediate cell survival, including FAK, Akt, and PI3K. FAK and Akt activation and decreased osteoblast death has also been observed upon the adsorption of fibronectin and vitronectin to hydroxyapatite/PLLA composite scaffolds. ${ }^{39}$

Alternatively, adsorbed protein layers may mitigate cell death via their alteration of the surface potential of the apatite coating or by modulation of the phase transformation rate of the apatite surface. Negatively charged surfaces of polarized hydroxyapatite ceramics are known to promote proliferation, while positively charged surfaces inhibit this response. ${ }^{30}$ The interaction of acidic proteins, such as BSA, to cationic sites on the apatite surface is also known to cause the net surface charge to become more negative. ${ }^{31}$ As such, the adsorption of BSA or FBS to the apatite layers in this study may alter surface charge sufficiently to improve cell adhesion and viability.

Adsorbed protein layers, alternatively, may increase the surface stability of the apatite through the modulation of phase transformation. ${ }^{3,23}$ Fibroblasts cultured on biphasic tricalcium phosphate-hydroxapatite (TCP-HA) ceramics in the absence of proteins are thought to rupture due to adhesion to the unstable TCP-HA surface, ${ }^{36}$ while the addition of serum components to their culture media is capable of mitigating this response. The adsorption of serum protein to these TCP-HA surfaces and the increased stability of this surface are proposed as the mechanism behind the increased survival of these fibroblasts. Additional studies on the surface charge and stability of the apatite surfaces created in this study are certainly warranted.

Previous in vitro work on MC3T3-E1 pre-osteoblasts has shown that elevated levels of both extracellular $\mathrm{Ca}^{2+}$ and $\mathrm{PO}_{4}{ }^{3-}$ decrease cell viability, possibly through their complexing as an ion pair or cluster, thus triggering receptor-mediated induction of apoptosis, or endocytic activation of cell death. ${ }^{2,27}$ Consistent with these studies, we confirmed that MC3T3-E1 cells, cultured on TCPS showed increasing levels of cell death upon supplementation with both extracellular $\mathrm{Ca}^{2+}$ and $\mathrm{PO}_{4}^{3-} \cdot \mathrm{Ca}^{2+}$ uptake into osteoblasts is 
thought to be mediated through several types of calcium channels including conventional L- and T-type channels ${ }^{5,20}$ and G-protein coupled receptors termed " $\mathrm{Ca}^{2+}$-sensing receptors" that respond to extracellular $\mathrm{Ca}^{2+}$ levels. ${ }^{7}$ Phosphate uptake by these cells has been attributed to the type III Na-Pi transporters, Pit-1 and Pit-2. ${ }^{6}$ While both $\mathrm{Ca}^{2+}$ and $\mathrm{PO}_{4}{ }^{3-}$ ions were needed to induce MC3T3-E1 cell death in this study, only specific inhibition of $\mathrm{PO}_{4}{ }^{3-}$ uptake was able to mitigate this response, indicating that cell death is sensitive to $\mathrm{PO}_{4}{ }^{3-}$ transport, and that this sensitivity has been shown to be $\mathrm{Ca}^{2+}$-dependent. ${ }^{2}$ In contrast, treatment with several $\mathrm{Ca}^{2+}$ channel blockers (i.e., nifedipine, verapamil, lanthanum chloride) was unable to change levels of cell death. Although the inhibition of the $\mathrm{Ca}^{2+}$ channels specific to the blockers used in this study failed to rescue cell viability, there may be other $\mathrm{Ca}^{2+}$ channels that play a more significant role in mediating cell viability and function, and efforts to determine intracellular $\mathrm{Ca}^{2+}$ levels will provide additional insight into this mechanism. Inhibition of extracellular $\mathrm{PO}_{4}{ }^{3-}$ transport into human osteoblasts and MC3T3-E1 cells by the Pit-1 inhibitor phosphonoformate (PFA) has been shown to reduce $\mathrm{Ca}^{2+} /$ $\mathrm{PO}_{4}{ }^{3-}$-induced cell death through its ability to modulate the mitochondrial membrane permeability transition as well as caspase-mediated apoptosis. ${ }^{1,2,32}$ The precise reason for why both extracellular $\mathrm{Ca}^{2+}$ and $\mathrm{PO}_{4}{ }^{3-}$ ions are needed to induce cell death in MC3T3E1 cells, and why specifically inhibiting $\mathrm{PO}_{4}{ }^{3-}$ uptake is able to rescue these cells remains unclear. In vascular smooth muscle cells, Pit-1 expression levels can be regulated by calcium concentration. ${ }^{26}$ As such, it is possible that increasing extracellular $\mathrm{Ca}^{2+}$ levels may increase $\mathrm{PO}_{4}{ }^{3-}$ uptake into MC3T3-E1 cells through its ability to regulate expression levels of the Pit-1 transporter. Further studies examining this possibility are certainly warranted.

As a rich source of $\mathrm{Ca}^{2+}$ and $\mathrm{PO}_{4}{ }^{3-}$, biomimetic apatite coatings may be able to induce cell death in a manner similar to extracellular $\mathrm{Ca}^{2+} / \mathrm{PO}_{4}{ }^{3-}$. In vitro, slightly acidic conditions can induce the dissolution of calcium phosphate ceramic materials and the release of $\mathrm{Ca}^{2+}$ and $\mathrm{PO}_{4}{ }^{3-}$ ions into the extracellular environment. ${ }^{4}$ The release of these ions may create a microenvironment surrounding the cell in which the levels of $\mathrm{Ca}^{2+}$ and $\mathrm{PO}_{4}{ }^{3-}$ are toxic. Subsequent $\mathrm{PO}_{4}{ }^{3-}$ uptake by the adherent MC3T3-E1 cell would then lead to $\mathrm{PO}_{4}{ }^{3-}$-induced cell death. In support of this theory, the rescue of MC3T3-E1 viability on bare apatite was induced in the current study upon treatment of the cells with PFA, whereas blocking $\mathrm{Ca}^{2+}$ uptake had no effect. Furthermore, the presence of an adsorbed protein layer may be sufficient for mitigating $\mathrm{PO}_{4}{ }^{3-}$ uptake by MC3T3-E1 cells in a similar manner as
PFA. However, the ICP-OES analysis of our study confirmed that the culture conditions used did not cause a noticeable release of ions from the apatite into solution. Rather, levels of extracellular calcium and phosphorus (as a component of $\mathrm{PO}_{4}{ }^{3-}$ ) were found to decrease upon incubation of apatite surfaces with $\alpha$-MEM, suggesting that the apatite surface may act to "pull-down" or "attract" $\mathrm{Ca}^{2+}$ and $\mathrm{PO}_{4}{ }^{3-}$ ions from the overlying medium towards the apatite surface. Similar decreases in the concentrations of $\mathrm{Ca}^{2+}$ and $\mathrm{PO}_{4}{ }^{3-}$ ions in culture medium have been reported with TCP-HA ceramics. ${ }^{35}$ How this "pull-down" might relate to MC3T3-E1 death on bare apatite layers remains unknown but it is tempting to speculate that an apatite-induced "flux" of $\mathrm{PO}_{4}{ }^{3-}$ ions through the microenvironment of the adherent cell could result in increased uptake of these ions, thus resulting in the induction of cell death.

\section{CONCLUSIONS}

In the absence of an adsorbed protein layer, bare apatites surfaces induce cell death of MC3T3-E1 preosteoblasts in serum-free media. However, it was determined that the mechanism of cell death was not mediated by caspase-dependent activation of apoptosis. Cell death could be prevented by pre-coating apatite surfaces with BSA or FBS proteins, or by pretreating the cells with PFA to inhibit $\mathrm{Na}-\mathrm{Pi}$ transport into the cell. These results suggest that adsorbed proteins may be capable of altering the bare apatite microenvironment to make it less detrimental to cell viability, possibly through the modulation of phosphate-mediated cell death.

\section{OPEN ACCESS}

This article is distributed under the terms of the Creative Commons Attribution Noncommercial License which permits any noncommercial use, distribution, and reproduction in any medium, provided the original author(s) and source are credited.

\section{REFERENCES}

\footnotetext{
${ }^{1}$ Adams, C. S., and I. M. Shapiro. Mechanisms by which extracellular matrix components induce osteoblast apoptosis. Connect Tissue Res. 44(Suppl 1):230-239, 2003.

${ }^{2}$ Adams, C. S., K. Mansfield, R. L. Perlot, and I. M. Shapiro. Matrix regulation of skeletal cell apoptosis. Role of calcium and phosphate ions. J. Biol. Chem. 276:2031620322, 2001.
} 
${ }^{3}$ Barbour, M. E., R. P. Shellis, D. M. Parker, G. C. Allen, and M. Addy. Inhibition of hydroxyapatite dissolution by whole casein: the effects of $\mathrm{pH}$, protein concentration, calcium, and ionic strength. Eur. J. Oral Sci. 116:473-478, 2008.

${ }^{4}$ Barrere, F., C. A. van Blitterswijk, and K. de Groot. Bone regeneration: molecular and cellular interactions with calcium phosphate ceramics. Int. J. Nanomedicine 1:317-332, 2006.

${ }^{5}$ Bergh, J. J., Y. Shao, E. Puente, R. L. Duncan, and M. C. Farach-Carson. Osteoblast $\mathrm{Ca}(2+)$ permeability and voltage-sensitive $\mathrm{Ca}(2+)$ channel expression is temporally regulated by 1,25-dihydroxyvitamin D(3). Am. J. Physiol. Cell Physiol. 290:C822-C831, 2006.

${ }^{6}$ Caverzasio, J., T. Selz, and J. P. Bonjour. Characteristics of phosphate transport in osteoblastlike cells. Calcif. Tissue Int. 43:83-87, 1988

${ }^{7}$ Chang, W., C. Tu, T. H. Chen, L. Komuves, Y. Oda, S. A. Pratt, S. Miller, and D. Shoback. Expression and signal transduction of calcium-sensing receptors in cartilage and bone. Endocrinology 140:5883-5893, 1999.

${ }^{8}$ Chen, Q., M. S. Kinch, T. H. Lin, K. Burridge, and R. L. Juliano. Integrin-mediated cell adhesion activates mitogenactivated protein kinases. J. Biol. Chem. 269:26602-26605, 1994.

${ }^{9}$ Chipuk, J. E., and D. R. Green. Do inducers of apoptosis trigger caspase-independent cell death? Nat. Rev. Mol. Cell Biol. 6:268-275, 2005.

${ }^{10}$ Chou, Y. F., W. A. Chiou, Y. Xu, J. C. Dunn, and B. M. $\mathrm{Wu}$. The effect of $\mathrm{pH}$ on the structural evolution of accelerated biomimetic apatite. Biomaterials 25:5323-5331, 2004.

${ }^{11}$ Chou, Y. F., J. C. Dunn, and B. M. Wu. In vitro response of MC3T3-E1 pre-osteoblasts within three-dimensional apatite-coated PLGA scaffolds. J. Biomed. Mater. Res. B Appl. Biomater. 75:81-90, 2005.

${ }^{12}$ Chou, Y. F., W. Huang, J. C. Dunn, T. A. Miller, and B. M. Wu. The effect of biomimetic apatite structure on osteoblast viability, proliferation, and gene expression. Biomaterials 26:285-295, 2005.

${ }^{13}$ Cowan, C. M., Y. Y. Shi, O. O. Aalami, Y. F. Chou, C. Mari, R. Thomas, N. Quarto, C. H. Contag, B. Wu, and M. T. Longaker. Adipose-derived adult stromal cells heal critical-size mouse calvarial defects. Nat. Biotechnol. 22:560-567, 2004.

${ }^{14}$ Ducheyne, P., S. Radin, and L. King. The effect of calcium phosphate ceramic composition and structure on in vitro behavior. I. Dissolution. J. Biomed. Mater. Res. 27:25-34, 1993.

${ }^{15}$ El-Ghannam, A., P. Ducheyne, and I. M. Shapiro. Effect of serum proteins on osteoblast adhesion to surface-modified bioactive glass and hydroxyapatite. J. Orthop. Res. 17:340-345, 1999.

${ }^{16}$ Giancotti, F. G., and E. Ruoslahti. Integrin signaling. Science 285:1028-1032, 1999.

${ }^{17}$ Globus, R. K., S. B. Doty, J. C. Lull, E. Holmuhamedov, M. J. Humphries, and C. H. Damsky. Fibronectin is a survival factor for differentiated osteoblasts. J. Cell Sci. 111(Pt 10):1385-1393, 1998.

${ }^{18}$ Golstein, P., and G. Kroemer. Cell death by necrosis: towards a molecular definition. Trends Biochem. Sci. 32:3743, 2007.

${ }^{19}$ Grigoriou, V., I. M. Shapiro, E. A. Cavalcanti-Adam, R. J. Composto, P. Ducheyne, and C. S. Adams. Apoptosis and survival of osteoblast-like cells are regulated by surface attachment. J. Biol. Chem. 280:1733-1739, 2005.
${ }^{20}$ Guggino, S. E., D. Lajeunesse, J. A. Wagner, and S. H. Snyder. Bone remodeling signaled by a dihydropyridineand phenylalkylamine-sensitive calcium channel. Proc. Natl Acad. Sci. U.S.A. 86:2957-2960, 1989.

${ }^{21}$ Guth, K., C. Campion, T. Buckland, and K. A. Hing. Effect of silicate-substitution on attachment and early development of human osteoblast-like cells seeded on microporous hydroxyapatite discs. Adv. Eng. Mater. 12:B26-B36, 2010.

${ }^{22}$ Hotchkiss, R. S., A. Strasser, J. E. McDunn, and P. E. Swanson. Mechanisms of disease cell death. N. Eng. J. Med. 361:1570-1583, 2009.

${ }^{23}$ Juhasz, J. A., S. M. Best, A. D. Auffret, and W. Bonfield. Biological control of apatite growth in simulated body fluid and human blood serum. J. Mater. Sci. Mater. Med. 19:1823-1829, 2008.

${ }^{24}$ Kay, M. I., R. A. Young, and A. S. Posner. Crystal structure of hydroxyapatite. Nature 204:1050-1052, 1964.

${ }^{25}$ Kilpadi, K. L., P. L. Chang, and S. L. Bellis. Hydroxylapatite binds more serum proteins, purified integrins, and osteoblast precursor cells than titanium or steel. J. Biomed. Mater. Res. 57:258-267, 2001.

${ }^{26} \mathrm{Li}, \mathrm{X} ., \mathrm{H}$. Y. Yang, and C. M. Giachelli. Role of the sodium-dependent phosphate cotransporter, Pit-1, in vascular smooth muscle cell calcification. Circ. Res. 98:905-912, 2006.

${ }^{27}$ Meleti, Z., I. M. Shapiro, and C. S. Adams. Inorganic phosphate induces apoptosis of osteoblast-like cells in culture. Bone 27:359-366, 2000.

${ }^{28}$ Nakayama, G. R., M. C. Caton, M. P. Nova, and Z. Parandoosh. Assessment of the Alamar Blue assay for cellular growth and viability in vitro. J. Immunol. Methods 204:205-208, 1997.

${ }^{29}$ Nelson, D. G. A., J. C. Barry, C. P. Shields, R. Glena, and J. D. B. Featherstone. Crystal morphology, composition, and dissolution behavior of carbonated apatites prepared at controlled $\mathrm{pH}$ and temperature. J. Colloid Interface Sci. 130:467-479, 1989.

${ }^{30}$ Ohgaki, M., T. Kizuki, M. Katsura, and K. Yamashita. Manipulation of selective cell adhesion and growth by surface charges of electrically polarized hydroxyapatite. J. Biomed. Mater. Res. 57:366-373, 2001.

${ }^{31}$ Reynolds, E. C., and A. Wong. Effect of adsorbed protein on hydroxyapatite zeta potential and Streptococcus mutans adherence. Infect. Immun. 39:1285-1290, 1983.

${ }^{32}$ Saunders, R., K. H. Szymczyk, I. M. Shapiro, and C. S. Adams. Matrix regulation of skeletal cell apoptosis III: mechanism of ion pair-induced apoptosis. J. Cell. Biochem. 100:703-715, 2007.

${ }^{33}$ Sawyer, A. A., K. M. Hennessy, and S. L. Bellis. Regulation of mesenchymal stem cell attachment and spreading on hydroxyapatite by RGD peptides and adsorbed serum proteins. Biomaterials 26:1467-1475, 2005.

${ }^{34}$ Steller, H. Mechanisms and genes of cellular suicide. Science 267:1445-1449, 1995.

${ }^{35}$ Suzuki, T., T. Yamamoto, M. Toriyama, K. Nishizawa, Y. Yokogawa, M. R. Mucalo, Y. Kawamoto, F. Nagata, and T. Kameyama. Surface instability of calcium phosphate ceramics in tissue culture medium and the effect on adhesion and growth of anchorage-dependent animal cells. J. Biomed. Mater. Res. 34:507-517, 1997. 
${ }^{36}$ Suzuki, T., R. Ohashi, Y. Yokogawa, K. Nishizawa, F. Nagata, Y. Kawamoto, T. Kameyama, and M. Toriyama. Initial anchoring and proliferation of fibroblast L-929 cells on unstable surface of calcium phosphate ceramics. J. Biosci. Bioeng. 87:320-327, 1999.

${ }^{37}$ Van Noorden, C. J. The history of Z-VAD-FMK, a tool for understanding the significance of caspase inhibition. Acta Histochem. 103:241-251, 2001.
${ }^{38}$ Williams, J. R., J. B. Little, and W. U. Shipley. Association of mammalian cell death with a specific endonucleolytic degradation of DNA. Nature 252:754-755, 1974.

${ }^{39}$ Woo, K. M., J. Seo, R. Y. Zhang, and P. X. Ma. Suppression of apoptosis by enhanced protein adsorption on polymer/hydroxyapatite composite scaffolds. Biomaterials 28:2622-2630, 2007. 